University of Michigan Law School

University of Michigan Law School Scholarship Repository

\title{
Policies to Expand Minority Entrepreneurship: Closing Comments
}

\author{
Michael S. Barr \\ University of Michigan Law School, msbarr@umich.edu
}

Available at: https://repository.law.umich.edu/book_chapters/2

Follow this and additional works at: https://repository.law.umich.edu/book_chapters

Part of the Banking and Finance Law Commons, Business Organizations Law Commons, Law and Race Commons, Law and Society Commons, and the Legislation Commons

\section{Publication Information \& Recommended Citation}

Barr, Michael S. "Policies to Expand Minority Entrepreneurship: Closing Comments." In Entrepreneurship in Emerging Domestic Markets: Barriers and Innovation, edited by G. Yago, J. R. Barth, and B. Zeidman, 141-50. The Milken Institute Series on Financial Innovation and Economic Growth, vol. 7. New York: Springer, 2008. [Based on comments delivered at the Conference on on Entrepreneurship in Low- and Moderate-Income Communities, November 3-4, 2005.]

This Book Chapter is brought to you for free and open access by the Faculty Scholarship at University of Michigan Law School Scholarship Repository. It has been accepted for inclusion in Book Chapters by an authorized administrator of University of Michigan Law School Scholarship Repository. For more information, please contact mlaw.repository@umich.edu. 


\title{
Policies to Expand Minority Entrepreneurship: Closing Comments
}

\author{
Michael S. Barr
}

\section{Introduction}

This has been a productive conversation. In my closing comments, I want to shift our focus somewhat, from entrepreneurship in low-income communities to minority entrepreneurship generally. I want to do so because many minority entrepreneurs are connected to or hire from low-income communities, and because minority entrepreneurs face critical barriers even when they attempt to create and grow firms outside of distressed communities. In this comment, I want to highlight key barriers and suggest five steps for Congress, the banking regulators, and business leaders that may help the United States benefit more fully from the talents of minority entrepreneurs.

\section{Minority Entrepreneurship}

\subsection{Trends in Minority Entrepreneurship}

Despite significant gains in minority entrepreneurship over the past decade, African-American-owned firms and Hispanic-owned firms are underrepresented relative to their proportion of the U.S. population. According to the most recent data, in 2002 there were more than four million minority-owned firms, employing nearly five million people, with more than $\$ 700$ million in revenues. ${ }^{1}$ Minority-owned firms constituted more than 17 percent of all U.S. firms,

\footnotetext{
M. S. Barr

University of Michigan Law School and The Brookings Institution.

Delivered at the Conference on Entrepreneurship in Low- and Moderate-Income

Communities, November 3-4, 2005, co-sponsored by the Kauffman Foundation and the Federal Reserve Bank of Kansas City.

msbarr@umich.edu

${ }^{1}$ U.S. Census Bureau, 2002 Economic Census, Survey of Business Owners (SBO).
} 
employed 4 percent of U.S. workers, and earned 3 percent of business revenues. $^{2}$ African-American-owned firms constituted 5 percent of all firms; Hispanics, 7 percent; and Asian Americans nearly 5 percent. ${ }^{3}$ African Americans and Hispanics each constituted more than 12 percent of the population, and Asian Americans, 3.6 percent. ${ }^{4}$ In 2002, African-American-owned businesses had $\$ 93$ billion in revenues; Hispanic firms had \$226 billion in revenues; and AsianAmerican-owned firms had $\$ 343$ billion in revenues. Three-quarters of minority-owned firms have no paid employees. African-American- and Hispanicowned firms overwhelmingly have no paid employees. ${ }^{5}$

From 1997-2002, minority-owned firms grew at a much faster rate than U.S. firms as a whole. The number of U.S. firms grew 10 percent, and receipts grew 22 percent over the period. At the same time, Hispanic-owned firms grew 31 percent in number, and 22 percent in receipts; African-American-owned firms grew 45 percent in number, and 30 percent in receipts; Asian-Americanowned firms grew 24 percent in number, but only 13 percent in receipts. ${ }^{6}$ Almost all of the growth occurred in firms with no paid employees; Hispanic firms with paid employees actually declined in number.

Despite overall growth for minority-owned firms, however, minority-owned firms failed at a higher rate than other firms. Minority-owned firms with employees in 1997 "had lower survival rates than non-minority-owned employer establishments" in the four years following. The survival rate for non-minority firms was 72.6 percent; 61 percent for African-American-owned firms; 68.6 percent for Hispanic owned firms; and 72.1 percent (close to the nonminority average) for Asian-American-owned firms. ${ }^{7}$

Minority entrepreneurship is growing, but still lags far behind the rates for whites. There likely are myriad reasons for these differences. Broader societal factors that influence minority entry and success in business, such as the significant gap in wealth between minority households and white households, ${ }^{8}$ and the effects of our educational system, are far beyond the scope of this comment.

\footnotetext{
${ }^{2}$ Ibid.

${ }^{3}$ Ibid.

${ }^{4}$ See U.S. Census Bureau, http://quickfacts.census.gov/qfd/states/00000.html.

${ }^{5}$ U.S. Census Bureau, 2002 SBO, supra.

${ }^{6}$ Ibid.

${ }^{7}$ Ibid.

${ }^{8}$ The median African-American household has about six to seven times less wealth than the median white household: $\$ 19,000$ compared to $\$ 120,900$. Ana M. Aizcorbe et al., Recent Changes in U.S. Family Finances: Evidence from the 1998 and 2001 Survey of Consumer Finances, 89 FED. Res. Bull. 1, 7-8 (2003). "The net worth of black and Hispanic college graduates is similar to the net worth of white high school graduates, and the net worth of black and Hispanic high school graduates is similar to the net worth of white high school dropouts." John Karl Scholz and Kara Levine, "U.S. Black-White Wealth Inequality: A Survey," 4 (2003), http://www.ssc.wisc.edu/ scholz/Research/Wealth_Survey_v5.pdf.
} 
But the next section describes financial and market barriers that affect minorities who pursue entrepreneurial endeavors.

\subsection{Barriers to Minority Entrepreneurship}

Minority entrepreneurs, like other entrepreneurs, need access to credit and equity to create and grow their businesses. They need access to business relationships that invite new opportunities. They need access to financial, technical, and managerial talent that enable businesses to thrive. In these areas, minority entrepreneurs may face significant barriers.

Small businesses in general have a harder time getting access to credit than larger firms in part because it is more difficult for them to demonstrate creditworthiness. Despite gains over the past decade in financial innovation and technology that make it possible for large banks to generate credit scores for small-business loans and sell government-guaranteed, real-estate secured, and other small business loans on secondary markets, ${ }^{9}$ small-business borrowers still rely disproportionately on a relatively small number of local lenders. They can provide credit based on judgment, relationships, and local knowledge. ${ }^{10}$ Relationship lending is critical for small firms. ${ }^{11}$ For minority firms, evidence suggests that this sometimes presents significant barriers to accessing credit.

A number of studies have determined that minority-owned small businesses have a more difficult time getting access to credit than other businesses even after controlling for a wide variety of factors related to creditworthiness. ${ }^{12}$ For example, one study found that African-American business owners receive smaller bank loans than similarly situated whites after controlling for net worth, education, age, and other factors. ${ }^{13}$ In the study, smaller loan size was

\footnotetext{
${ }^{9}$ See, e.g., Zoltan Acs, The Development and Expansion of Secondary Markets for Small Business Loans, in J. Blanton et al., eds., "Business Access to Capital and Credit," a Federal Reserve System Research Conference, 8-9 March 8-9 1999.

${ }^{10}$ See, e.g., Arnoud W.A. Boot, Relationship Banking: What do we Know? 9 J. of Fin. Intermediation 7, 9-12 (2000).

${ }^{11}$ See, e.g., Brian Uzzi and James Gillespie, "What Small Firms get Capital and at What Cost: Notes on the Role of Social Capital and Banking Networks," in Business Access to Capital and Credit, supra.

${ }^{12}$ See Michael S. Barr, et al., "The Community Reinvestment Act: Its Impact on Lending in Low-Income Communities in the United States," in E. Mayo and C. Guene, eds., Banking and Social Cohesion (2001).

13 Timothy Bates, "Commercial Bank Financing of White- and Black-Owned Small Business Startups", 31Quarterly Review of Economics \& Business 64 (1991); Timothy Bates, "Unequal Access: Financial Institution Lending to Black- and White-Owned Small Business Startups", 19Journal of Urban Affairs 487 (1997).
} 
found to be an important determinative of higher failure rates for AfricanAmerican-owned firms. ${ }^{14} \mathrm{~A}$ follow-up study found that, all other things being equal, African-Americans received only $\$ 0.92$ worth of additional credit for every additional dollar of equity they put into their businesses, while white borrowers received $\$ 1.17 .{ }^{15}$ White borrowers were able to leverage their education and experience into better loans, while black applicants with similar educational backgrounds and experience were not. ${ }^{16}$

Another study found that African-American-owned firms, controlling for firm creditworthiness, firm size, age and business location, industry type, and education of owners, were about 25 percent more likely to be denied a loan than white-owned businesses. ${ }^{17}$ In addition, African-American firms paid more in interest, even after accounting for business credit histories. ${ }^{18}$ Moreover, African-American-owned firms and Hispanic-owned firms were much more likely to report not applying for a loan for fear of rejection, even after controlling for firm creditworthiness. ${ }^{19}$ Controlling for a wide range of factors relating to the risk of borrowers and the market structure of the banking sector, another study found that African-American-owned firms and Hispanic-owned firms were one-third more likely to be turned down for business loans than their similarly situated white counterparts. ${ }^{20}$ The study also found that, all else being equal, Hispanic firms (but not African-American firms) paid higher interest rates than white borrowers as a function of market concentration. ${ }^{21}$ African-Americanowned businesses, white-owned businesses, and Hispanic-owned businesses had similar demand for credit. ${ }^{22}$

A final study adds further controls for the economic health of local communities. ${ }^{23}$ In this study, African-American-owned firms again were found to have lower approval rates than white firms, but the differences were smaller than in other studies. The study found no statistically different disparities between Hispanic-owned and white-owned firms. ${ }^{24}$ As their authors are aware, each

\footnotetext{
${ }^{14}$ Ibid

${ }^{15}$ Bates, Unequal Access supra.

${ }^{16}$ Ibid.

${ }^{17}$ David Blanchflower, Phillip Levine, and David Zimmerman, "Discrimination in the Small Business Credit Market,” NBER Working Paper No. 6840, December 1998.

18 Ibid.

${ }^{19}$ Ibid

${ }^{20}$ Ken Cavalluzzo and Linda Cavalluzzo, Market Structure and Discrimination: The Case of Small Business, 30 Journal of Money, Credit, and Banking 771 (1998).

${ }^{21}$ Ibid.

22 Ibid.

${ }^{23}$ Raphael Bostic and Patrick Lampani, "Racial Differences in Patterns of Small Business Finance: The Importance of Local Geography," Business Access to Capital and Credit, supra. ${ }^{24}$ Ibid.
} 
study suffers from limitations of available data, ${ }^{25}$ and more research is warranted to further our understanding of minority firms' access to credit.

In addition to credit, businesses need equity, both for business formation and expansion. Equity provides the patient capital firms need in the early stages of development before they can generate sufficient cash flow, and gives firms leverage to access credit. Equity is also critical to weathering downturns in the economy. And such capital is essential to expand businesses rapidly to capture gains from innovation and new market opportunities. The U.S. venture capital industry is the envy of the world for its ability to translate innovative ideas from new firms into commercial reality. ${ }^{26}$

Yet venture capital, critical for the rapid growth of small firms, is likely to be harder to attract for minority entrepreneurs than credit. Even during the heyday of venture capital's growth in the late 1990s, venture capital funding was highly concentrated in a few sectors and geographic regions. ${ }^{27}$ High technology, Internet, biomedical, and related firms focused in a handful of geographic areas attracted the bulk of venture capital funding. Most small businesses, including minority-owned firms, rely, instead, on banks, finance companies, credit cards, and their family and friends for financing. In that regard, the significant wealth gap affects comes into play in reducing the ability of many minority firms to start new businesses with the equity they need. Minority-owned firms are not a core focus of most venture capital firms.

Yet when minority firms are able to access venture capital, their performance has proved strong. ${ }^{28}$ Venture capital firms focused on minority-owned businesses had 20 percent returns in the 1990s, on a par with private equity funds generally. ${ }^{29}$ Two dozen minority-focused venture capital firms had raised a total of more than $\$ 1.3$ billion in equity by 2000 , a peak year for venture capital. The money came mostly from pension funds, but also from banks, insurance companies, and other sources. ${ }^{30}$ These funds have invested in a more diverse range of sectors than the venture capital industry as a whole. ${ }^{31}$

Business relationships and expertise are just as critical to business formation and growth as is access to capital. ${ }^{32}$ Business relationships contribute to new

\footnotetext{
${ }^{25}$ See, e.g., Richard W. Lang, The Conference on Business Access to Capital and Credit: An Overview, ** What's this? >> Business Access to Capital and Credit, supra.

${ }^{26}$ See Ronald J. Gilson, Engineering a Venture Capital Market: Lessons from the American Experience, 55 Stanford L. Rev. 1067 (2003).

${ }^{27}$ See generally, National Venture Capital Association at http://www.nvca.org.

${ }^{28}$ Timothy Bates \& William Bradford, Minorities \& Venture Capital: A New Wave in American Business (Kauffman Foundation, 2003).

${ }^{29}$ Ibid.

${ }^{30}$ Ibid

${ }^{31}$ Ibid.

${ }^{32}$ See U.S. Department of the Treasury, "BusinessLINC: Business-to-Business Relationships that Increase the Economic Competitiveness of Firms" (1998).
} 
economic opportunities as well as to a firm's reputation in the market. Business relationships provide opportunities for sharing business expertise, and for managerial development. ${ }^{33}$ Minority entrepreneurs need connections to business networks that provide these benefits, but many minority entrepreneurs often find themselves outside such networks.

\section{Policies to Expand Minority Entrepreneurship}

These barriers to minority entrepreneurship may be amenable to change. Despite remaining problems, the growth of minority entrepreneurship and the expansion of access to capital during the 1990s suggest that positive market developments for minority entrepreneurs can be catalyzed further by both policy and concerted action by the private sector. This comment outlines five key steps that Congress, the banking regulators, and business leaders can take to open up opportunities for minority entrepreneurs.

\subsection{New Markets Tax Credit}

In the bipartisan Community Renewal Tax Relief Act of $2000,{ }^{34}$ Congress enacted a New Markets Tax Credit (NMTC) to spur new equity investments for business growth. Private investment funds compete for allocations from the Treasury Department, authorizing the funds to issue as much as $\$ 15$ billion of equity on which investors may claim tax credits worth 39 percent of their investment. The NMTC leaves investment decisions in the hands of market participants. Investment funds that receive allocations raise private funds, mostly from passive institutional investors, just as in the venture capital industry generally, and then invest or lend to businesses in low- and moderate-income communities. Unlike many federal programs, these communities are drawn broadly so that large areas of the United States are eligible. Under a recent change, these investment funds also may invest in minority-owned or other firms that otherwise lack adequate access to loans or equity investments, regardless of location. ${ }^{35}$

The NMTC draws on the strength of America's venture capital and commercial real estate industries. Equity raised using the NMTC can spur growth of minority businesses and should be expanded. Congress extend the NMTC for another five years, ${ }^{36}$ and should provide greater flexibility to investment funds

\footnotetext{
${ }^{33}$ Ibid.

${ }^{34}$ Pub. L. No. 106-554 (December 21, 2000).

${ }^{35}$ American Jobs Creation Act of 2004, Pub. L. No. 108-357, §221 (October 22, 2004).

${ }^{36}$ See S. 1800 and H.R. 3957 (introduced September 29, 2005).
} 
to offer deeper credit allocations to investors in order to broaden the range of investment strategies these funds can profitably pursue.

\subsection{Capital Access Programs}

State-run capital access programs (CAPs) have a strong track record of expanding access to credit for small businesses. ${ }^{37}$ Under these programs, operated by about 20 states, small businesses pay an insurance fee that goes into a loan loss reserve fund held at the originating bank; the insurance premium is matched by the state CAP. The bank makes its own underwriting, pricing, and insurance decisions. Since they were first launched in 1986, state CAPs have enabled more than $\$ 1.5$ billion in small-business loans to be made at low cost and low risk, reaching significant numbers of minority entrepreneurs. ${ }^{38}$ As one banker put it: "CAP borrowers typically are emerging businesses lacking the kind of track record they would normally need to establish eligibility for a conventional loan. Often they need working capital, but lack the necessary collateral, or the principals have insufficient personal assets. They are unlikely to be able to attract venture capital or private equity. But these businesses often are the backbone of their communities. Supporting them is the right thing to do, and a CAP loan is often the right way to meet their needs." 39

Despite the success of CAPs in supporting small-business growth, many states are finding it difficult to maintain the programs in the face of severe state budget constraints. The federal government could bolster state-run CAPs by providing funding to states for initiating or increasing their programs, and reaching out to minority entrepreneurs. For example, if the federal government were to provide a 2 percent match into state-funded loan loss reserves, a $\$ 1$ billion federal government investment over the next five years would leverage $\$ 50$ billion in bank loans to small businesses.

\subsection{Data Collection for the Community Reinvestment Act}

Under the Community Reinvestment Act (CRA), banks and thrifts are examined and rated on their performance in providing loans, investments, and

\footnotetext{
${ }^{37}$ See U.S. Department of the Treasury, "Capital Access Programs: A Summary of Nationwide Performance" (2001).

${ }^{38}$ Ibid. at 16.

39 Thomas Doherty, Make No Little Plans: How a Midwest Bank Uses a Capital Access Program to Help Small Businesses, Office of the Comptroller of the Currency, Community Developments, Winter 2003.
} 
services in their entire community. ${ }^{40}$ Bank regulators also take account of CRA performance during merger reviews. It is likely that CRA has helped to increase lending to small businesses. ${ }^{41}$ One study found, for example, that CRA increases the number of small businesses that can access credit by 4 percent to 6 percent. ${ }^{42}$ Moreover, the study determined that the increased lending to small businesses induced by CRA provided benefits to the real economy in the form of increased payrolls and reduced bankruptcies without any evidence that such lending either crowded out other financing available to small businesses or adversely affected bank profitability or loan performance. ${ }^{43}$

Despite these and other gains from CRA, recent regulatory changes could undermine progress. ${ }^{44}$ Under a banking agency joint rule, banks and thrifts with less than $\$ 1$ billion in assets are considered "small" for purposes of CRA and exempt from small-business lending disclosure requirements and full-scope CRA review. Even banks and thrifts that are part of mammoth holding companies would be considered small if the bank or thrift itself held less than $\$ 1$ billion in assets. Under current law, banks and thrifts are considered small if they have assets of only $\$ 250$ million or less, and are independent, or are part of a holding company with less than $\$ 1$ billion in bank and thrift assets. Dramatically increasing the asset threshold, and considering institutions small even if they are affiliated with large holding companies are misguided policies.

Small businesses rely disproportionately on smaller banks for retail services and lending in their local communities. Thus, it makes little sense to stop collecting small-business data from these smaller banks, or evaluating institutions on their small-business lending and retail services. Even more problematic is the plan to ignore the asset size of the holding company in defining a bank as "small." Holding companies provide scale economies and expertise to their subsidiaries in complying with bank regulations.

CRA small-business data collection should be enhanced by including information about loan applications that are denied, distinguishing better among the sizes and types of loans made (for example, small-business credit card accounts compared with capital equipment loans), and providing more precise information about the geographic location where loan proceeds are used. And the new community development test for intermediate-sized banks must take account explicitly of small business lending.

\footnotetext{
${ }^{40}$ See 12 U.S.C. $\$ 2901-2908$.

${ }^{41}$ See Michael S. Barr, "Credit Where it Counts: The Community Reinvestment Act and Its Critics," 80 New York University Law Review 513 (2005); Jonathan Zinman, "The Efficacy and Efficiency of Credit Market Interventions: Evidence from the Community Reinvestment Act" (Harvard Univ. Joint Ctr. For Housing Studies, Working Paper CRA02-2, 2002).

${ }^{42}$ See Zinman, supra, at 20.

${ }^{43}$ Ibid. at 3-4.

${ }^{44}$ See Michael S. Barr, Credit Where It Counts: Maintaining a Strong Community Reinvestment Act, Brookings Institution Metropolitan Program Research Brief, May 2005.
} 


\subsection{Fair Lending Disclosure}

Under the Home Mortgage Disclosure Act, creditors are required to report on the race, ethnicity, gender, and income of home mortgage borrowers and loan applicants in order to advance the goal of equal opportunity in home mortgage lending. There is evidence that such disclosures have contributed to increased home ownership opportunities for minority households over the past decade. ${ }^{45}$

By contrast, Federal Reserve Board regulations under the Equal Credit Opportunity Act (ECOA) bar creditors from even voluntarily recording the race, ethnicity, and gender of small business and consumer borrowers and loan applicants. This rule is an unwarranted restriction on the ability of lenders to obtain the information they need to serve minority small-business borrowers. ${ }^{46}$ Banks that want to design programs to serve minority entrepreneurs cannot track progress in their programs compared to other lending.

The inability to measure whether new marketing or products are reaching minority small businesses is a significant barrier to expanding minority access to business credit. Moreover, the lack of available data on small business and consumer lending undermines the ability of fair lending enforcement agencies to monitor and enforce ECOA. The Federal Reserve Board has the authority to alter their regulations to permit creditors to record such data, and twice has taken up the issue, but has declined to lift the prohibition. ${ }^{47}$ The board should finalize the rule it proposed previously to permit creditors to keep track of such information as a means of expanding access to credit to minority entrepreneurs. ${ }^{48}$

\subsection{Business-to-Business Partnerships}

Business relationships between minority-owned small- and medium-sized businesses and larger firms can be mutually beneficial. Minority-owned firms may be cut off from business opportunities because they lack connections to business networks. Greater levels of engagement between executives of larger firms and minority-owned businesses can increase opportunities for minority firms to

\footnotetext{
${ }^{45}$ See Barr, Credit Where it Counts, supra.

${ }^{46}$ See Letter from U.S. Department of the Treasury, U.S. Department of Justice, U.S. Department of Housing and Urban Development, Office of the Comptroller of the Currency, Office of Thrift Supervision, U.S. Small Business Administration, Federal Trade Commission, and Office of Federal Housing Enterprise Oversight, to Board of Governors of the Federal Reserve System, November 15,1999.

${ }^{47}$ See Board of Governors of the Federal Reserve System, Final rule, Equal Credit Opportunity, 68 Fed. Reg. 13143, March 18, 2003.

${ }^{48}$ Board of Governors of the Federal Reserve System, Proposed rule, Equal Credit Opportunity, 64 Fed. Reg. 44582, August 16, 1999.
} 
form partnerships and generate new business, and larger corporations can benefit from a diversified supplier base, flexible production, and innovations by smaller firms. Access to business opportunities and relationships can enhance business credibility and growth potential, thereby increasing minority firms' access to both debt and equity for expansion.

The National Urban League, the Business Roundtable, and the Kauffman Foundation launched a partnership recently to open one-stop business advice centers in a number of communities around the country. This effort builds on BusinessLINC, an initiative led by the Business Roundtable and launched by President Clinton and then Treasury Secretary Robert E. Rubin. It links Fortune 500 and other large companies with smaller firms. ${ }^{49}$ These linkages provide smaller firms with business opportunities, advice, and technical assistance. These are not government programs, but private-sector-led, market-tested initiatives to bring the experience of larger corporations to minority-owned firms, which are often cut off from business networks. BusinessLINC has established more than 20 chapters. Cleveland's has launched a \$25 million venture fund with support from local corporate leaders, including Sandy Cutler, the chief executive of Eaton Corporation. The most important factor in these programs is the engagement of the chief executives of major companies. As Ramani Ayer, chairman and CEO of the Hartford Financial Services Group, has said, "This program is the right thing to do from a corporate responsibility standpoint. And frankly, it is the smart thing to do from a competitive standpoint. Shareholders clearly benefit from our ability to partner with the brightest, most creative talent available, which we might just miss without this type of outreach program."

\section{Conclusion}

Minority entrepreneurs are playing an increasingly important role in the United States, but may face important barriers. Access to capital, business expertise, and market opportunities are essential for entrepreneurs to succeed. Congress should expand the New Markets Tax Credit and fund state-run Capital Access Programs. Banking regulators should maintain a strong Community Reinvestment Act and enhance fair lending disclosure. Business leaders should look to minority entrepreneurs for new partnerships that enhance shareholder value and strengthen community. Targeted policy initiatives and the focused attention of America's business leaders can contribute to the growth of minority entrepreneurship in the years ahead.

\footnotetext{
${ }^{49}$ See Michael S. Barr, "Access to Financial Services in the $21^{\text {st }}$ Century: Five Opportunities for the Bush Administration and the 107th Congress," 16 Notre Dame Journal of Law, Ethics \& Public Policy 447, 455 (2002); BusinessLINC Report, supra.
} 